\title{
ASMENŲ, SERGANČIŲ ŠIRDIES IR KRAUJAGYSLIŲ LIGOMIS, BURNOS SVEIKATOS BŪKLE்S VERTINIMAS
}

\author{
Guoda Jurkẻnaitė, Kristina Saldūnaitė, Jūratẻ Zūbienė, Vilija Andruškevičienė, \\ Ingrida Vasiliauskienè, Jolanta Siudikienè \\ Lietuvos sveikatos mokslu universiteto Medicinos akademijos Odontologijos fakultetas
}

Raktažodžiai: burnos higiena, burnos sveikata, periodonto ligos, širdies ir kraujagyslių sistemos ligos.

\begin{abstract}
Santrauka
Momentinis tyrimas buvo atliktas $2017 \mathrm{~m}$. lapkričio $-2018 \mathrm{~m}$. vasario ménesiais. Tyrime dalyvavo 100 pacientų, sergančių širdies-kraujagyslių ligomis, nuo 55 - 75 metų amžiaus. Tyrimo metu buvo atlikta anketinè apklausa ir klinikinis burnos ištyrimas pagal PSO rekomendacijas, nustatyti dantų ėduonies intensyvumo KPI-D, burnos higienos OHI-S, periodonto sveikatos PSR indeksai.

Dažniausiai širdies ir kraujagyslių sistemos ligomis sergantys pacientai skundèsi burnos sausumu. Paaiškejo, kad pas burnos higienistą visiškai nesilanko 74 proc. apklaustujų ir tik 5 proc. lankosi kas 6 menesius ar dažniau. Dantų èduonies paplitimas siekè 98 proc., o 91 proc. tirtujų pacientų turèjo periodonto patologijos požymius. KPI-D vidurkis - 26,7.

Sergančių širdies ir kraujagyslių ligomis burnos sveikata buvo prasta, burnos priežiūra - netinkama, didžioji dalis asmenų nesilanko pas burnos higienistą. Prastesni burnos higienos ịpročiai, burnos sausumas, didesni periodonto ir dantų èduonies sergamumo rodiklai buvo susiję su amžiumi ir ligos trukme.
\end{abstract}

\section{Ivadas}

Pasaulyje, ypač išsisvysčiusiose šalyse, stebimas vyresnio amžiaus žmonių daugejjimas. Žmonèms, vyresniems nei 55 metai, stebimas dažnesnis sisteminių ligų pasireiškimas, kurių pagrindinę dalį sudaro širdies ir kraujagyslių ligos [1].

Ši patologija Lietuvoje, kaip ir visoje Europoje, buvo ir tebèra pagrindinè mirties priežastis [2]. Pagal Higienos instituto sveikatos informacijos centro mirties priežasčių registrą, Lietuvoje 2016 metais net 56,2 proc. mirčiu buvo dèl širdies ir kraujagyslių ligų [3].

Pastebèta, kad vyresnio amžiaus žmonėms labiau pasireiškia ir burnos ertmès sveikatos sutrikimai: dantų èduonis, periodonto ligos, dantų paslankumas ar net netekimas, gleivinès pažeidimai, sausumas burnoje [4,5].

Moksliniais tyrimais nustatyta, kad periodonto ligos paplitusios tarp 20-50 proc. visų gyventojų. O lètinis periodonto audinių uždegimas yra pagrindinè dantų praradimo priežastis [6]. Be to, periodonto patologija net 15-19 proc. gali padidinti širdies ir kraujagyslių ligų riziką. Ir atvirkščiai - vaistai, kurie vartojami širdies ir kraujagyslių ligoms gydyti, gali pakenkti pacientų burnos sveikatai [7, 8]. İrodyta, kad asmenys, sergantys periodonto liga, turi didesnę riziką susirgti ir širdies-kraujagyslių sistemos ligomis $[9,10]$.

Darbo tikslas: išanalizuoti asmenų, sergančiu širdies ir kraujagyslių ligomis, burnos sveikatos būklę.

\section{Tyrimo medžiaga ir metodai}

Vienmomentinis tyrimas buvo atliktas $2017 \mathrm{~m}$. lapkričio2018m. vasario mènesiais VŠI Jonavos ligoninèje. Tiriamaji kontingentą sudare 55-75 metų ir vyresnio amžiaus asmenys $(\mathrm{n}=100)$, sergantys širdies kraujagyslių ligomis. Tyrime dalyvavo 31 proc. vyrų ir 69 proc. moteru. Tiriamieji buvo suskirstyti i tris grupes: $55-64 \mathrm{~m}, 65-74 \mathrm{~m}$ ir $75 \mathrm{~m}$ ir daugiau.

Tyrimui buvo sudarytas klausimynas ir klinikinio ištyrimo anketa, remiantis PSO rekomenduojama dantų éduonies ir periodonto būklès vertinimo metodika, skaičiuoti KPI-D (vieno asmens èduonies pažeistų, plombuotų, išrautų dantų skaičius), OHI-S (burnos higienos), PSR (periodonto sveikatos) indeksai.

Tyrimui gautas LSMU MA Bioetikos centro pritarimas (protokolo Nr. BEC-BH(B)-48). Statistinè analizė atlikta SPSS 21.0 paketu. Duomenys buvo analizuojami pasitelkiant aprašomąą statistiką. Hipotezèms tikrinti buvo naudojama aprašomoji statistika ir $\mathrm{X}^{2}$ kriterijus. Pasirinkto reikšmingumo lygmuo - 0,05 [11].

\section{Rezultatai ir jų aptarimas}

Anketinès apklausos duomenys parodé, kad 50 proc. tyrimo dalyvių širdies ir kraujagyslių ligomis sirgo daugiau nei 10 metų, statistiškai reikšmingai daugiau moterų nei vyrų 
$(\mathrm{p}<0,05) .35$ proc. respondentų nurodè, kad serga arterine hipertenzija, 26 proc.tiriamujų sirgo arterine hipertenzija ir širdies ritmo sutrikimais, 39 proc.- kitomis širdies ir kraujagyslių ligomis (išemine širdies liga, širdies nepakankamumu, miokardo infarktu).

Analizuojant gautus rezultatus nustatyta, kad 38 proc. apklausos dalyvių medikamentus, skirtus gydyti širdies ir kraujagyslių sistemos ligas, naudojo daugiau nei 10 metų,

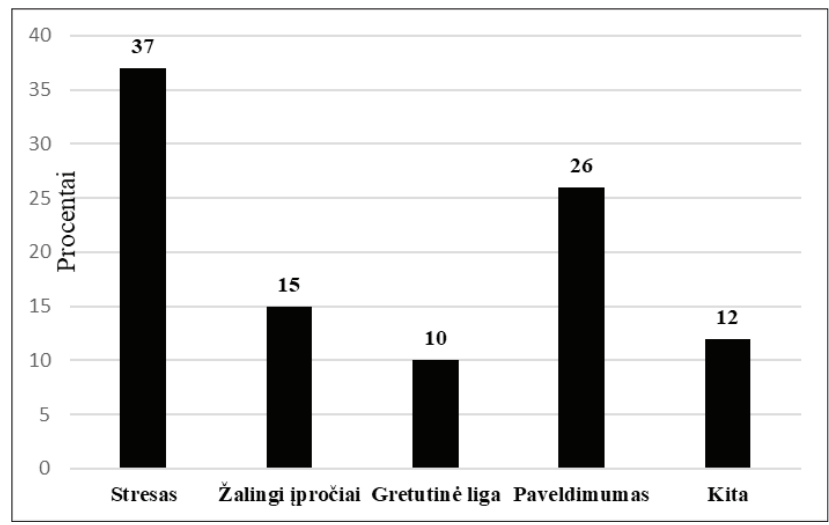

1 pav. Apklausos dalyvių pasiskirstymas pagal širdies ir kraujagyslių sistemos ligų priežastis.

1 lentelè. Sergančiųjų širdies ir kraujagyslių ligomis pasiskirstymas pagal burnos pokyčius, atsižvelgiant ị amžių.

$\left(\chi^{2}=22,824 ; * * * \mathrm{p}<0,05\right)$

\begin{tabular}{|l|c|c|c|}
\hline \multirow{2}{*}{ Reikšmės } & $\mathbf{5 5 - 6 4} \mathbf{~ m .}$ & $\mathbf{6 5 - 7 4} \mathbf{~ m .}$ & $\begin{array}{c}\mathbf{7 5} \text { m. ir } \\
\text { daugiau }\end{array}$ \\
\cline { 2 - 4 } & Proc. (N) & Proc. (N) & Proc. (N) \\
\hline Nebuvo burnos pakitimų & $29,6(8)$ & $2,7(1)$ & $22,2(8)$ \\
\hline Burnos sausumas & $18,5(5)^{*}$ & $45,9(17)^{*} *$ & $58,3(21)^{*} *$ \\
\hline $\begin{array}{l}\text { Burnos sausumas, } \\
\text { dantenų pakitimai }\end{array}$ & $7,4(2)$ & $18,9(7)$ & $8,3(3)$ \\
\hline Dantenų pakitimai & $14,8(4)$ & $8,1(3)$ & $5,6(2)$ \\
\hline Kiti burnos pokyčiai & $29,6(8)$ & $24,3(9)$ & $5,6(2)$ \\
\hline
\end{tabular}

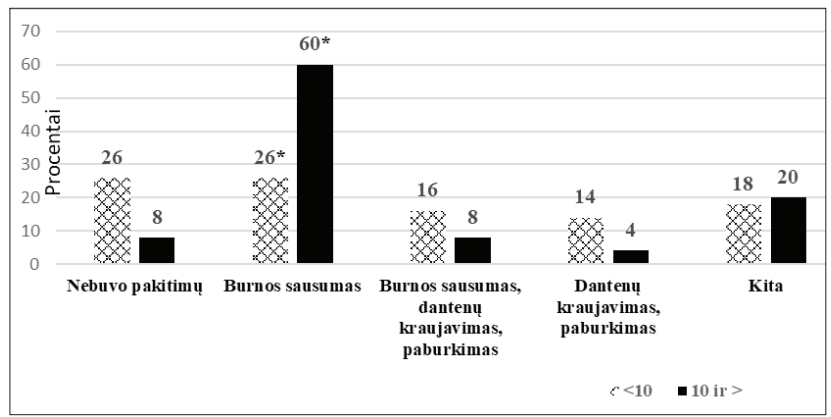

2 pav. Sergančiųjų širdies ir kraujagyslių ligomis burnos pokyčių pasiskirstymas, atsižvelgiant ị ligos trukmę $\left(\chi^{2}=15,649 ; 11 \mathrm{~s}=4 ; * \mathrm{p}<0,05\right)$. o 52,8 proc. tiriamujų konstatavo dažną medikamentų naudojimą.

Paklausus respondentų, kokia, jų manymu, pagrindinè priežastis turèjo įtakos širdies ir kraujagyslių sistemos ligoms atsirasti, 37 proc. apklaustujų nurodè stresą, 26 proc.-paveldimumą, nes širdies ligomis sirgo jų tèvai ar seneliai. Taip pat buvo paminèti žalingi ịpročiai, tarp kurių dažniausiai buvo nurodytas rūkymas arba alkoholio vartojimas (1 pav.).

Mokslinès literatūros analizè atskleidžia, kad šie veiksniai įtakūs ne tik širdies ir kraujagyslių sistemos ligoms atsirasti [12], bet ir didina periodonto ligų išsivystymo riziką ir progresavimą.

Visi tyrimo dalyviai nurodè, kad susirgę širdies ir kraujagyslių ligomis pastebejo pokyčius burnoje. Daugiausia tiriamujų jautė burnos sausumą, statistiškai reikšmingai daugiau moterų nei vyrų (atitinkamai 52,2 proc. ir 22,6 proc.) $\left(\chi^{2}=9,758 ; 11 \mathrm{~s}=4 ; \mathrm{p}<0,05\right)[1$ lentelè]. Taip pat nustatyta, kad vyriausioje amžiaus grupejje didesnè dalis asmenų skundèsi burnos sausumu, palyginus su jaunesnio amžiaus tiriamųjų grupèmis $(\mathrm{p}<0,05)(1$ lentelè).

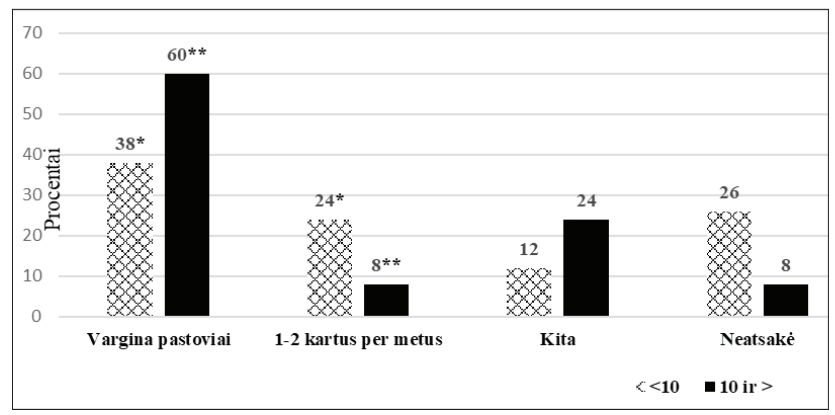

3 pav. Sergančiųjų širdies ir kraujagyslių ligomis pasiskirstymas pagal burnos pokyčių pasireiškimo dažnį, atsižvelgiant i ligos trukmę $\left(\chi^{2}=13,234 ; 11 \mathrm{~s}=3 ;{ }^{*},{ }^{*} \mathrm{p}<0,05\right)$.

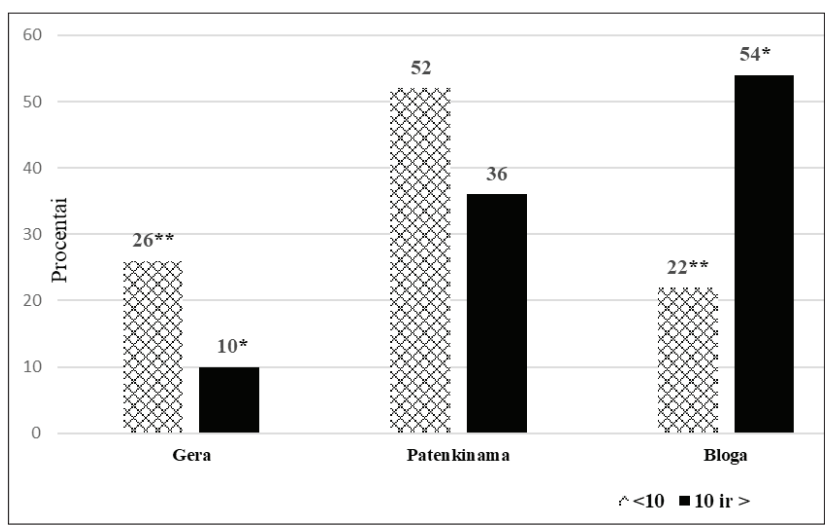

4 pav. Sergančiųuu širdies ir kraujagyslių ligomis pasiskirstymas pagal burnos sveikatos vertinimą, atsižvelgiant ị ligos trukmę $\left(\chi^{2}=11,747 ; 11 \mathrm{~s}=2 ; * * * \mathrm{p}<0,05\right)$. 
Mūsų tyrimo metu gautas statistiškai reikšmingas ryšys tarp burnos pokyčių, kuriuos nurodè respondentai, ir sergamumo širdies ir kraujagyslių sistemos ligomis trukmès. Pastebėta, kad burnos sausumu daugiausia skundesi tie pacientai, kurių ligos anamnezè buvo daugiau nei 10 metų (2 pav.). Panašius tyrimų duomenis pateikia ir kiti tyrejai, teigiantys, kad burnos sausumą gali sukelti vaistai, naudojami širdies-kraujagyslių ligoms gydyti, taip pat įtakos gali turèti ir ligos trukmè [13].

Nuo širdies ir kraujagyslių sistemos ligų trukmès taip pat statistiškai reikšmingai priklauso ir kitų pokyčių burnoje (dantenų pakitimai, kraujavimas iš dantenų) pasireiškimo dažnis. Pastebeta, kad pokyčiai burnoje pastoviai vargino tuos asmenis, kurie širdies ir kraujagyslių sistemos ligomis sirgo 10 metų ir daugiau. Pacientai, kurie sirgo mažiau nei 10 metų, dažniausiai nurodè, kad pakitimus burnoje jaučia retai $(\mathrm{p}<0,05)(3$ pav. $)$

Ivertinus apklausos tyrimo rezultatus paaiškèjo, kad statistiškai reikšmingai didesnè dalis asmenų, kurie širdies ir kraujagyslių ligomis sirgo iki 10 metų, burnos sveikatą vertino geriau, palyginus su tiriamaisiais, kurių ligos trukmé buvo ilgesnè (4 pav.).

Daugelio tyrimo dalyvių burnos higienos ịpročiai buvo netinkami: tik 50 proc. respondentų nurodè, kad dantis valosi du kartus per dieną, o 26 proc.-vieną kartą, 10 proc.asmenų valo dantis po kiekvieno valgymo, 9 proc.-kelis kartus per savaitę, 5 proc. tyriamujų niekada nevalo dantų. Jaunesnèje amžiaus grupèje du kartus per dieną valančių dantis asmenų buvo statistiškai reikšmingai daugiau nei vyresnio amžiaus tiriamujų grupejje [2 lentelè].

Respondentai dažniausiai naudoja dantų šepetėlị ir pastą, o kitas papildomas burnos higienos priemones (tarpdančių valymo šepetėlius, liežuvio valiklį, burnos skalavimo skysčius) naudojo tik 14 proc. tiriamujjų. Net 74 proc. apklaustujų niekada nebuvo atliekamos profesionalios burnos higienos procedūros, 11 proc.asmenų lankosi rečiau nei kartą

2 lentelė. Sergančiujų širdies ir kraujagyslių ligomis pasiskirstymas pagal dantų valymo dažnị, atsižvelgiant ị amžių $\left(\chi^{2}=23,261\right.$; $11 \mathrm{~s}=8 ; \mathrm{p}<0,05)$.

\begin{tabular}{|l|c|c|c|}
\hline \multirow{2}{*}{ Reikšmės } & $\mathbf{5 5 - 6 4} \mathbf{~ m . ~}$ & $\mathbf{6 5 - 7 4} \mathbf{~ m .}$ & $\begin{array}{c}\mathbf{7 5} \mathbf{~ m . ~ i r ~ d a u - ~} \\
\text { giau }\end{array}$ \\
\cline { 2 - 4 } & Proc. (N) & Proc. (N) & Proc. (N) \\
\hline Vieną kartą dienoje & $14,8(4)$ & $32,4(12)$ & $27,8(10)$ \\
\hline Du kartus per dieną & $\mathbf{7 7 , 8 ( 2 1 ) *}$ & $51,4(19)$ & $\mathbf{2 7 , 8 ( 1 0 ) *}$ \\
\hline $\begin{array}{l}\text { Po kiekvieno val- } \\
\text { gymo }\end{array}$ & $3,7(1)$ & $10,8(4)$ & $13,9(5)$ \\
\hline $\begin{array}{l}\text { Kelis kartus per sa- } \\
\text { vaitę }\end{array}$ & $\mathbf{0 ( 0 ) * *}$ & $5,4(2)$ & $\mathbf{1 9 , 4}(\mathbf{7})^{* *}$ \\
\hline Niekada nevalo & $3,7(1)$ & $0(0)$ & $11,1(4)$ \\
\hline
\end{tabular}

per metus, 10 proc. - kartą per metus ir tik 5 proc.respondentų nurodè, kad profesionalią burnos higieną atlieka kas 6 mėnesius ir dažniau. Respondentai, kurių išsilavinimas buvo aukštesnis, statistiškai reikšmingai dažniau lankèsi pas burnos higienistą (5 pav.).

Panašius duomenis pateikia ir kiti autoriai, jie nustate, kad net 64 proc. pacientų, sergančių širdies ir kraujagyslių ligomis, nesilanko pas burnos higienistą, o 4 proc. lankosi kas 6 mènesius $[7,14]$. Taigi, tiek mūsų atliktame tyrime, tiek užsienio autorių tyrimų rezultatai rodo, kad respondentai mažai žino apie profesionalios burnos higienos svarbą ir neatlieka jos reguliariai, o tai ịrodo nepakankamą burnos ir dantų priežiūrą, didina burnos ligų atsiradimo riziką.

Ivertinus respondentų burnos higieną (OHI-S), nustatyta patenkinama ir bloga burnos higienos būkle buvo 64,2 proc. tirtų žmonių. Statistiškai reikšmingai daugiau moterų (19 proc.) nei vyrų ( 9 proc. burnos higiena buvo gera $(p<<0,05)$. Jauniausioje amžiaus grupejje respondentų burnos higienos būklè buvo statistiškai reikšmingai geresnè (13 proc.) nei vyriausioje amžiaus grupejje (21 proc.) $(\mathrm{p}<<0,05)$. Panašius duomenis pateikia ir kitos studijos, kur bloga burnos higienos būklè buvo apie 60 proc. tirtu pacientų, o gera - iki 3,3 proc. respondentų [7,14].

Klinikiniu sergančiųjų širdies kraujagyslių ligomis burnos tyrimu nustatyta, kad dantų būklè - prasta. Dantų eduonies paplitimas tiriamojoje grupeje siekè 98 proc., sveikus dantis turèjo tik 2 proc. pacientų, o 40 proc. visų tirtų respondentų buvo bedančiai. Kauno mieste atlikto tyrimo duomenys taip pat parodè itin didelị sergamumą dantų èduonimi vidutinio ir senyvo amžiaus žmonių grupèse [15]. Vertinant dantų eduonies intensyvumą, buvo apskaičiuotas didelis vidutinis KPI-D rodiklis 26,7. Nevienodas dantų ėduonies intensyvumas buvo moterų ir vyrų grupėse, didesnès vidutinės KPI- D

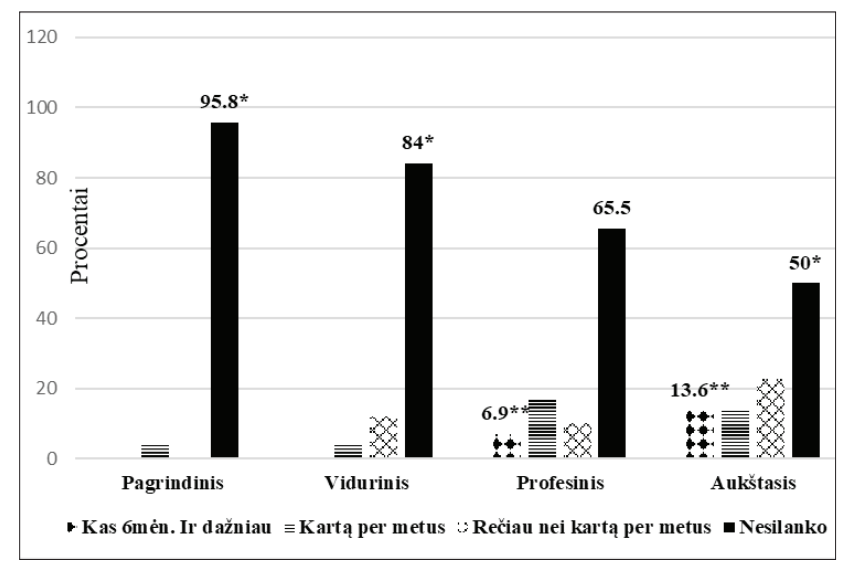

5 pav. Sergančiujų širdies ir kraujagyslių ligomis pasiskirstymas pagal lankymosi pas burnos higienistą dažni, atsižvelgiant ị išsilavinimą $\left(\chi^{2}=18,772 ; 11 \mathrm{~s}=9 ; * * * \mathrm{p}<0,05\right)$ 
rodiklio reikšmės buvo moterų grupėse. Analizuojant duomenis, paaiškẻjo, kad dantų netekimas susijęs su amžiumi: daugiausia pašalintų dantų buvo vyriausioje amžiaus grupeje (75 metai ir daugiau ) (68,5 proc), 65-74 m. grupejje - 46,1 proc., o jauniausioje grupeje-32,6 proc. $(\mathrm{p}<<0,05)$. Panašūs dantų edduonies intensyvumo rodikliai gauti ir Austrijoje atliktame moksliniame tyrime, kuriame suaugusių žmonių KPI-D buvo 26,3 [16].

Analizuojant tiriamujų periodonto audinių sveikatos duomenis, nustatyta, kad 91 proc. tirtujų pacientų turi periodonto patologijos požymius, taigi galima teigti, kad periodonto būklè bloga. Didžiausi pažeidimai buvo nustatyti viršutinio ir apatinio žandikaulių šoniniuose šeštadaliuose. 74 proc. pacientų nustatytos $1,5-3,5 \mathrm{~mm}$ patologinès dantenų kišenès, o mažiausi pažeidimai rasti viršutinio žandikaulio priekinių dantų srityje (kraujavimas po zondavimo) -4 2,9 proc. Tyrimas atskleidè, kad pažengę periodonto audinių pažeidimai diagnozuoti statistiškai reikšmingai dažniau vyriausioje amžiaus grupejje (29,6 proc.) nei jauniausioje amžiaus grupèje $(8,3$ proc.) $(\mathrm{p}<<0,05) .2008 \mathrm{~m}$. atlikto epidemiologinio tyrimo duomenimis, 94 proc. vyresnio amžiaus kauniečių sirgo periodonto audinių ligomis [17]. Tyrimų, nagrinejjančių, ar periodontologinis pacientų gydymas sumažintų širdies ir kraujagyslių ligų pasireiškimą, atlikta nedaug. Tačiau yra studijų, įrodančių, kad, atlikus periodontologini gydymą sumažeja uždegimo mediatorių organizme, endotelio bei lipidų funkcija gereja. Negydomos periodonto audiniu ligos keičia organizmo imuninio atsako mechanizmą, didina organizmo imlumą ir jautrumą, todèl sisteminių ligų, taip pat ir širdies kraujagyslių ligų, išsivystymo rizika didèja $[9,18]$.

\section{Išvados}

1. Sergančių širdies ir kraujagyslių ligomis burnos sveikata buvo prasta: $90 \%$ tiriamujų buvo diagnozuota ịvairaus sunkumo periodonto audinių patologija ir didelis dantų èduonies intensyvumas.

2. Tiriamujų burnos priežiūros ịpročiai - netinkami, didžioji dalis asmenų niekada neatliko profesionalios burnos higienos procedūrų. Visi respondentai nurodè pokyčius burnoje, o sergantys daugiau nei dešimt metų širdies kraujagyslių sistemos ligomis dažniausiai skundèsi burnos sausumu. Prastesni burnos priežiūros ir sveikatos rodikliai buvo susiję su amžiumi ir ligos trukme.

3. Reikia gerinti sergančiųų širdies-kraujagyslių ligomis burnos sveikatos priežiūrą, ypatingą dèmesį skiriant vyresnio amžiaus asmenims.

\section{Literatūra}

1. Ahmad MS, Bhayat A, Zafar MS, Al-Samadani KH. The impact of hyposalivation on quality of life (QoL) and oral health in the aging population of Al Madinah Al Munawarrah. Int J Environ Res Public Health 2017;Apr 2014(4):pii:E445.

https://doi.org/10.3390/ijerph14040445

2. Rinkūnienė E., Petrulionienė Ž. Zdanevičiūtė I., Dženkevičiūtė V. Mirtingumo nuo širdies ir kraujagyslių ligų tendencijos Lietuvoje ir Europos sajungos šalyse. Medicinos teorija ir praktika, 2013;T19(2):130-136.

3. Higienos institutas. Sveikatos informacijos centras. Mirties priežastys 2016. Vilnius, 2017.

4. León S, Giacaman RA. Reality and challenges of the oral health for older adults in Chile and the role of a new discipline: geriatric dentistry. Rev Med Chil 2016;Apr;144(4):496-502. https://doi.org/10.4067/S0034-98872016000400011

5. Lucchese A. Streptococcus mutans antigen I/II and autoimmunity in cardiovascular diseases. Autoimmun Rev 2017;16(5):456460 .

https://doi.org/10.1016/j.autrev.2017.03.009

6. Xu S, Song M, Xiong Y, Liu X, He Y, Qin Z. The association between periodontal disease and the risk of myocardial infarction: a pooled analysis of observational studies. BMC Cardiovasc Disord 2017;17(1):50. https://doi.org/10.1186/s12872-017-0480-y

7. Rasouli-Ghahroudi AA, Khorsand A, Yaghobee S, Rokn A, Jalali M, Masudi S, Rahimi H, Kabir A. Oral health status, knowledge, attitude and practice of patients with heart disease. ARYA Atheroscler 2016;12(1):1-9.

8. Costerton J, Keller D. Oral periopathogens and systemic effects. Gen Dent 2007 May-Jun;55(3):210-215.

9. Bendoraitytė A, Kiudelytė-Stancevičienė E, Andruškevičienė V. Periodonto ir lètinių neinfekcinių ligų ryšys. Bendrosios praktikos Lietuvos gydytojas, 2018;7(22):466-470.

10. Bains R, Bains VK. Lesions of endodontic origins:An emerging risk factor for coronary heart diseases. Indian Heart Journal 2018;70:S431-34.

https://doi.org/10.1016/j.ihj.2018.07.004

11. Sapagovas J., Šaferis V., Jurènienė K., Jurkonienė R., Šimatonienė V., Šimoliūnienė R. Statistikos ir informatikos pagrindai. KMU, 2007;65.

12. Rinkūnienė E, Petrulionienė Ž, Laucevičius A, Ringailaitė E, Laučytė A. Tradicinių rizikos veiksnių paplitimas tarp sergančių išemine širdies liga. Medicina (Kaunas), 2009;45(2):140-145. https://doi.org/10.3390/medicina45020018

13. Wu XF, Huang JY, Chiou JY, Chen HH, Wei JC, Dong L. Increased risk of coronary heart disease among patients with primary Sjögren's syndrome: a nationwide population-based cohort study. Sci Rep 2018;8:2209. https://doi.org/10.1038/s41598-018-19580-y

14. Vasiliauskas K., Jankauskaitė Ž., Slabšinskienė E. Aterosklerozinès kilmės širdies ir kraujagyslių ligomis sergančių pacientų burnos higienos ir periodonto būklès ịvertinimas. Visuomenès sveikata, 2017;2(77):51-56. 
15. Zūbienė J. Kauno miesto vidutinio ir senyvo amžiaus žmonių odontologinių ligų epidemiologinès situacijos vertinimas. Daktaro disertacija. 2010.

16. Glodny B, Nasseri P, Crismani A, Schoenherr E, Luger AK, Bertl K, Petersen J. The occurrence of dental caries is associated with atherosclerosis. Clinics (Sao Paulo) 2013 Jul; 68(7):946-953.

https://doi.org/10.6061/clinics/2013(07)10

17. Zūbienė J, Klumbienė J, Tamošiūnas A, Milčiuvienė S. Kauno miesto senyvo amžiaus žmonių periodonto ligų paplitimo ir burnos higienos būklès įvertinimas. Sveikata, 2008;18(6):20182024.

18. Górski B, Górska R. The impact of periodontal treatment on inflammatory markers and cellular parameters associated with atherosclerosis in patients after myocardial infarction. Cent Eur J Immunol 2018;43(4):442-452.

https://doi.org/10.5114/ceji.2018.81356

\section{EVALUATION OF ORAL HEALTH STATUS AMONG PATIENTS WITH CARDIOVASCULAR DISEASES}

G.Jurkėnaitė, K.Saldūnaitė, J.Zūbienė, V.Andruškevičienė, I.Vasiliauskienè, J.Siudikienè

Keywords: oral hygiene, cardiovascular diseases, oral health, periodontal disease

Summary

The goal of the study is to analyze the oral health of patients diagnosed with cardiovascular diseases and its correlation with heart diseases.
Materials and methods. An instant survey was conducted from 2017 November to 2018 February. The respondents of the research consisted of patients from 55 years old to patients 75 years old. An anonymous questionnaire-based survey was employed and a clinical oral health test was performed. The following indices were used for result assessment: DMF, OHI, PSR.

Results. Most often, patients diagnosed with cardiovascular diseases complained of dry mouth which could be caused by medications or long duration of the diseases. It was revealed that as many as 74 proc. had not seen a dental hygienist at all. Around 5 proc. of the respondents had dental hygienist's appointments every 6 months or more often. Tooth decay was a problem for $98 \%$ of the respondents while the assessment in terms of periodontitis revealed 1,5-3,5-mm-deep periodontal pockets.

Conclusions. Patients with cardiovascular disease oral health was poor, oral care was inappropriate, and most people did not visit the oral hygienist. Inferior oral hygiene habits, dry mouth, higher periodontal and dental caries rates were associated with age and duration of disease.

Correspondence to: ksaldunaite@yahoo.com

Gauta 2019-05-14

\section{KVIEČIAME PRENUMERUOTI "SVEIKATOS MOKSLŲ" ŽURNALĄ 2019 METAIS!}

Žurnalas "Sveikatos mokslai” (Index Copernicus, EBSCO host (Academic Search Complete), Gale (Academic OneFile), ProQuest (Ulrich's, Summon), Australia (ERA) 2012 Journal List (ERA ID 34962) skirtas visų specialybiu gydytojams, slaugytojams ir kitiems specialistams, spausdina mokslinius straipsnius lietuvių, anglų kalbomis. Reikalavimai straipsniams atitinka mokslo leidiniams keliamus reikalavimus. Žurnalas kioskuose neparduodamas. Žurnalą, kuris leidžiamas kartą per du mènesius, galima užsiprenumeruoti visuose Lietuvos pašto skyriuose, taip pat internetu: www.prenumeruok.lt

Prenumeratos kaina nesikeičia: visiems metams - 36 EUR, šešiems mėnesiams - 18 EUR, keturiems mẻnesiams - 12 EUR, dviem mėnesiams - 6 EUR. Prenumeratos kodas: 5348.

Žurnalo autoriams straipsnių spausdinimas mokamas. 